\title{
Peran Self-Compassion terhadap Psychological Well-Being Pengajar Muda di Indonesia Mengajar
}

\author{
Atikah Fairuz Renggani dan Putu Nugrahaeni Widiasavitri \\ Program Studi Psikologi, Fakultas Kedokteran, Universitas Udayana \\ putunugrahaeni.w@unud.ac.id
}

\begin{abstract}
Abstrak
Psychological well-being merupakan aspek penting yang perlu dimiliki pengajar muda selama bertugas di daerah pedalaman Indonesia. Salah satu faktor yang dapat memengaruhi psychological well-being adalah self compassion. Self compassion merupakan kemampuan individu untuk memberikan perhatian dan kepedulian terhadap diri sendiri ketika mengalami tantangan, masalah, dan kesulitan dalam hidup serta mampu melihat hal tersebut sebagai bagian dari pengalaman hidup manusia. Penelitian ini merupakan penelitian kuantitatif untuk mengetahui peran self compassion terhadap psychological well-being pengajar muda di Indonesia Mengajar. Subjek dalam penelitian ini berjumlah 60 orang pengajar muda yang sedang bertugas di daerah pedalaman dengan menggunakan teknik simple random sampling. Alat ukur dalam penelitian ini menggunakan skala self compassion dengan reliabilitas sebesar 0,943 dan skala psychological well-being dengan reliabilitas sebesar 0,915. Hasil uji regresi linier sederhana menunjukan $\mathrm{R}=0,792$ dan adjusted $R$ square sebesar 0,628 . Hal tersebut menjelaskan bahwa self compassion memiliki peran sebesar $62,80 \%$ terhadap psychological well-being. Koefisien beta terstandarisasi self compassion sebesar 0,792 dan signifikansi 0,000 $(\mathrm{p}<0,05)$, sehingga dapat disimpulkan bahwa self compassion berperan terhadap psychological well-being pengajar muda di Indonesia Mengajar.
\end{abstract}

Kata Kunci: Self-compassion, Psychological well-being, Pengajar Muda, Indonesia Mengajar

\begin{abstract}
Psychological well-being is an important aspect for pengajar muda who are on duty in the countryside of Indonesia. One factor that could effect of psychological well-being is self compassion. Self compassion is ability to give attention and care toward oneself while in the challenge, problem, or trouble and ability to see them all as a part of human experience. This research used quantitative research to determine the role self compassion on psychological well-being of pengajar muda in Indonesia Mengajar. The subject for this study were 60 pengajar muda who are on duty in the countryside of Indonesia with simple random sampling technique. The measuring instrument of this research used self compassion scale with the reliability 0.943 and psychological well-being scale with the reliability 0.915 . The result of linearity regression showed $\mathrm{R}=0,792$ and adjusted $\mathrm{R}$ square equal $=0,628$. This showed that variable self compassion had role at $62.80 \%$ on psychological well-being. Standardized beta coefficient of self compassion was 0.792 at significance of $0.000(\mathrm{p}<0.05)$, it was mean that self compassion contributed to psychological well-being pengajar muda in Indonesia Mengajar.
\end{abstract}

Keywords: Self-compassion, Psychological well-being, Pengajar Muda, Indonesia Mengajar 


\section{LATAR BELAKANG}

Kesejahteraan (well-being) secara psikologis merupakan aspek penting untuk dikembangkan selain mengutamakan kesejahteraan secara fisik, sosial maupun materi. Pandangan tentang well-being terdiri dari dua pandangan utama yaitu kebahagiaan (subjective well-being) dan pengoptimalan potensi diri (psychological well-being). Psychological wellbeing bukan hanya melihat kebahagiaan sebagai indikator utama kesejahteraan (well-being) dalam diri individu, tetapi kemampuan individu dalam mengaktualisasikan potensi diri untuk mencapai kesejahteraan (well-being) secara psikologis (Singh, Mohan \& Anasseri, 2012).

Psychological well-being merupakan kriteria kesehatan mental positif yang penting untuk dikembangkan dalam diri manusia, karena individu yang sejahtera (well-being) secara psikologis memiliki penilaian positif terhadap diri sendiri, mampu menjalin hubungan yang hangat dengan orang lain, mampu mengendalikan lingkungan eksternal, memiliki tujuan hidup, mampu bertahan dari tekanan sosial, serta mampu mengoptimalkan potensi diri (Singh, Mohan \& Anasseri, 2012).

Psychological well-being penting untuk dikembangkan dalam diri manusia khususnya pada masa dewasa awal. Masa dewasa awal merupakan periode penyesuaian diri terhadap pola kehidupan dan harapan sosial baru terkait tugas perkembangan pada masa dewasa awal (Hurlock, 1980). Salah tugas perkembangan pada masa dewasa awal yaitu mulai bekerja dalam suatu jabatan (Santrock, 2012). Psychological wellbeing penting untuk dikembangkan pada masa dewasa awal khususnya dalam menjalankan tugas perkembangan agar dapat berjalan optimal. Individu dengan psychological well-being yang baik mampu berfungsi secara penuh dalam mengoptimalkan potensi diri dan berpengaruh terhadap pengoptimalan performa kerja pada tingkat terbaiknya (Usman, 2017).

Dalam dunia pendidikan, pekerjaan menjadi seorang guru merupakan salah satu komponen utama yang paling menentukan terhadap proses pembelajaran sebagai upaya mencerdaskan generasi bangsa (Suparlan, 2006). Terdapat berbagai program pendidikan yang berupaya untuk mencerdaskan generasi bangsa, yaitu Komunitas jendela, Indonesia Menyala, Skholatanpabatas, Book for mountain, Saung mimpi dan Indonesia Mengajar (Zufar, 2015). Secara khusus, Indonesia Mengajar merupakan program pendidikan yang berupaya untuk mengirimkan generasi terbaik bangsa sebagai seorang guru selama satu tahun di daerah pedalaman yang disebut sebagai pengajar muda (Indonesia Mengajar, 2017).

Selama bertugas di daerah pedalaman, pengajar muda diharapkan mampu mengoptimalkan potensi diri sebagai seorang guru, mampu menjalin hubungan yang hangat dengan siswa dan masyarakat di daerah pedalaman, memiliki target dan pencapaian, serta mampu mengatur lingkungan eksternal agar proses pembelajaran dapat berjalan optimal. Salah satu aspek penting yang perlu dimiliki pengajar muda selama bertugas di daerah pedalaman yaitu psychological well-being.
Idealnya, pengajar muda dengan psychological well-being yang baik mampu mengoptimalkan potensi diri, mampu bekerja secara produktif untuk memberikan kontribusi terbaiknya dalam meningkatkan mutu serta kualitas pendidikan Indonesia, memiliki komitmen dalam bekerja, mampu menciptakan hubungan yang harmonis dengan siswa dan masyarakat di daerah pedalaman serta mampu bertahan terhadap berbagai tekanan selama bertugas di daerah pedalaman.

Preliminary study dilakukan kepada empat orang alumni pengajar muda terkait tantangan yang dihadapi selama bertugas di daerah pedalaman. Pengajar muda menjelaskan bahwa dirinya tidak merasakan tantangan atau kendala selama bertugas di daerah pedalaman. Pengajar muda menjelaskan bahwa tantangan yang dihadapi khususnya menjadi seorang guru mampu dihadapi dengan perasaan sabar dan bahagia (Renggani, 2017). Berdasarkan uraian tersebut, dapat disimpulkan bahwa pengajar muda memiliki psychological well-being yang baik. Hal ini berkaitan dengan kriteria fungsi psikologi positif yang menjelaskan bahwa individu dengan psychological well-being yang baik memiliki evaluasi positif terhadap pengalaman hidup, mampu merasakan kebahagiaan serta terbebas dari berbagai tekanan psikologis dalam hidupnya (Singh, Mohan \& Anasseri, 2012).

Preliminary study dilakukan dengan pengajar muda lainnya dan ditemukan bahwa pengajar muda merasa stres ketika menghadapi situasi yang menekan dalam menghadapi tantangan selama bertugas di daerah pedalaman. Pengajar muda mengakui stres karena guru honorer dan guru kontrak yang jarang hadir ke sekolah dan menyebabkan pengajar muda mengajar enam kelas dalam satu hari. Pengajar muda juga diharapkan mampu menguasai materi pembelajaran sebelum mengisi enam kelas dalam waktu yang terbatas, dan seringkali menghadapi siswa-siswi yang sulit di atur di dalam kelas (Renggani, 2017).

Pekerjaan menjadi seorang guru, merupakan salah satu pekerjaan yang dapat menimbulkan stres. Hal ini disebabkan karena kondisi dan lingkungan kerja yang terlalu banyak memberikan tugas dan tanggungjawab sehingga membuat individu merasa stres dan berpengaruh terhadap rendahnya psychological well-being dalam diri individu (Issom \& Makbulah, 2017). Hal ini sejalan dengan pandangan Clemente, Hezomi, Allahverdipour, Jafarabadi, dan Safaian (2016) stres memiliki hubungan yang signifikan terhadap psychological well-being. Artinya, semakin tinggi tingkat stres maka semakin besar pengaruhnya terhadap rendahnya psychological well-being dalam diri individu.

Berdasarkan uraian sebelumnya, kemampuan pengajar muda dalam menghadapi berbagai tantangan dan situasi yang menekan mampu memengaruhi perbedaan taraf psychological well-being yang dimiliki pengajar muda. Oleh karena itu, terdapat pengajar muda dengan psychological well-being pada taraf yang tinggi, sementara pengajar muda lainnya memiliki psychological well-being pada taraf yang rendah. Salah satu faktor yang dapat memengaruhi psychological well-being yaitu self compassion. Neff dan Costigan (2014) menjelaskan bahwa memperlakukan diri sendiri dengan penuh kasih sayang 
dan kepedulian ketika menghadapi tantangan, masalah, atau kesulitan dalam hidup mampu meningkatkan psychological well-being dalam diri individu.

Self compassion merupakan kemampuan individu dalam memberikan kebaikan dan kepedulian terhadap diri sendiri ketika mengalami tantangan, masalah, dan kesulitan dalam hidup serta memahami bahwa segala tantangan, masalah, dan kesulitan dalam hidup merupakan bagian dari pengalaman hidup manusia. Self compassion mampu melindungi individu dari berbagai emosi negatif seperti stres, cemas dan depresi serta menyeimbangkannya dengan emosi positif dan berpengaruh terhadap peningkatan psychological well-being (Neff, 2011).

Self compassion merupakan sumber utama dari kebahagiaan eudaimonik (psychological well-being). Pendekatan hedonik (subjective well-being) yaitu mencari kebahagiaan dengan melibatkan pengalaman bahagia dan menghindari rasa sakit, self compassion tidak menghindari rasa sakit melainkan memeluk rasa sakit dengan memberikan kebaikan kepada diri sendiri (self kindness) dan berpengaruh terhadap peningkatan psychological well-being dalam diri individu khususnya pada dimensi penerimaan diri (self acceptance) (Neff dan Costigan, 2014).

Self compassion khususnya aspek common humanity mampu meningkatkan keterampilan individu dalam bersikap imbang untuk memberikan kebaikan kepada diri sendiri dan orang lain ketika mengalami masalah, kesulitan dan ketidaksempurnaan dalam hidup sehingga dapat berpengaruh terhadap peningkatan psychological well-being khususnya kemampuan individu dalam menjalin hubungan yang positif dengan orang lain (positive relation with others) (Neff dan Costigan, 2014).

Salah satu aspek dari self compassion yaitu mindfulness berperan penting terhadap peningkatan kesejahteraan (wellbeing) dalam diri individu. Mindfulness mampu melindungi diri dari stres, perasaan cemas dan depresi. Mindfulness membawa individu kembali kepada keadaan saat ini, membantu individu secara sadar dalam menentukan keputusan, perilaku dan kegiatan secara mandiri sehingga dapat berpengaruh terhadap peningkatan kesejahteraan (wellbeing) khususnya pada dimensi kemandirian (autonomy) (Neff, 2011).

Neff (2011) menjelaskan bahwa self compassion merupakan kemampuan individu dalam memberikan pemahaman dan kebaikan terhadap diri sendiri (self kindness) ketika mengalami tantangan, masalah, kesulitan tanpa harus mengkritik atau menghakimi diri sendiri secara berlebihan. Ketika individu mampu menerima diri apa adanya dan belajar untuk menjadi pribadi yang lebih baik (self kindness), maka self compassion secara langsung dapat meningkatkan kesejahteraan (well-being) khususnya pada dimensi pertumbuhan pribadi (personal growth).

Pengajar muda diharapkan mampu memberikan kepedulian dan perhatian kepada diri sendiri sebelum memberikan kepedulian dan perhatian kepada siswa-siswi dan masyarakat setempat. Individu dengan self compassion yang baik mampu peduli dan memberikan perhatian kepada diri sendiri ketika mengalami masalah dalam hidup dan berpengaruh terhadap peningkatan psychological well-being dalam diri individu. Pengajar muda dengan psychological well-being yang baik mampu mengoptimalkan potensi diri secara maksimal, mampu bekerja secara produktif serta mampu memberikan kontribusi terbaiknya sebagai agen pendidikan dalam rangka meningkatkan mutu serta kualitas pendidikan Indonesia. Berdasarkan pemaparan yang telah dijelaskan sebelumnya, perlu diketahui lebih jauh bagaimana peran self compassion terhadap psychological well-being pengajar muda di Indonesia Mengajar.

\section{METODE PENELITIAN}

\section{Variabel dan Definisi Operasional}

Variabel penelitian adalah segala bentuk yang telah ditetapkan oleh peneliti seperti atribut, sifat, nilai dari orang, objek, atau kegiatan yang memiliki variasi tertentu untuk dipelajari dan kemudian ditarik kesimpulanya (Sugiyono, 2013). Variabel bebas dalam penelitian ini adalah self compassion. Variabel tergantung dalam penelitian ini adalah psychological wellbeing. Definisi operasional merupakan suatu definisi mengenai variabel yang dirumuskan berdasarkan karakteristikkarakteristik variabel yang diamati (Azwar, 2014). Berikut definisi operasional variabel bebas dan variabel tergantung dalam penelitian ini, yaitu:

\section{Self-compassion}

Self compassion adalah kemampuan individu untuk memberikan perhatian dan kepedulian terhadap diri sendiri ketika menghadapi tantangan, masalah dan kesulitan dalam hidup serta melihat tantangan, masalah dan kesulitan dalam hidup merupakan bagian dari pengalaman hidup manusia. Pengukuran menggunakan skala self compassion dengan ketentuan semakin tinggi skor total yang diperoleh maka semakin tinggi self compassion yang dimiliki subyek.

Psychological well-being

Psychological well-being merupakan pencapaian penuh atas potensi yang dimiliki individu untuk mencapai kesejahteraan psikologis meliputi evaluasi positif terhadap diri sendiri (self accaptance), mampu mengelola lingkungan eksternal (environmental mastery), mampu berpikir dan bertindak secara mandiri (autonomy), mampu mengembangkan potensi dalam diri (personal growth), memiliki tujuan hidup (purpose in life) serta mampu menjalin hubungan yang harmonis dengan orang lain (positive relations with others). Pengukuran menggunakan skala psychological well-being dengan ketentuan semakin tinggi skor total yang diperoleh, maka semakin tinggi psychological well-being yang dimiliki subyek.

\section{Responden}

Populasi adalah wilayah generalisasi yang terdiri atas obyek atau subyek yang mempunyai kualitas dan karakteristik tertentu yang ditetapkan oleh peneliti untuk dipelajari dan kemudian ditarik kesimpulannya (Sugiyono, 2013). Populasi dalam penelitian ini adalah pengajar muda di Indonesia Mengajar yang sedang bertugas di daerah pedalaman. Sampel adalah bagian dari jumlah dan karakteristik yang mewakili populasi (Sugiyono, 2013). Sampel dalam penelitian memiliki 
ciri yang representatif (mewakili) terhadap populasi, sehingga dapat memberikan hasil akhir atau kesimpulan dari populasi secara keseluruhan (Azwar, 2014). Adapun, karakteristik sampel yang akan menjadi subyek dalam penelitian ini, diantaranya : Pertama, pengajar muda yang sedang bertugas di daerah pedalaman, karena pengajar muda sudah memahami situasi lingkungan setempat dan menghadapi tantangan selama bertugas di daerah pedalaman. Kedua. bersedia untuk berpartisipasi dalam penelitian ini.

\section{Tempat Penelitian}

Penelitian ini dilakukan dengan menyebarkan kuesioner secara online kepada pengajar muda yang sedang bertugas di daerah pedalaman. Penyebaran kuesioner dilakukan pada tanggal 2 Agustus hingga 9 Agustus 2017.

\section{Alat Ukur}

Alat ukur self compassion disusun sendiri oleh peneliti berdasarkan aspek self compassion yang dikembangkan oleh Neff (2003) yaitu self kindness, common humanity, dan mindfulness. Alat ukur psychological well-being menggunakan modifikasi skala psychological well-being yang disusun oleh Ryff (1989). Penelitian diawali dengan melakukan uji validitas dan reliabilitas terhadap alat ukur penelitian sebelum diberikan kepada subyek penelitian.

Uji validitas dalam penelitian ini menggunakan validitas isi dan validitas konstrak. Validitas isi dilakukan untuk melihat apakah aitem-aitem dalam alat ukur memiliki relevansi dengan indikator perilaku berdasarkan penilian professional judgement yang dianggap ahli pada bidangnya (Azwar, 2014). Pada penelitian ini, professional judgement dilakukan oleh dua dosen dari Program Studi Psikologi, Fakultas Kedokteran, Universitas Udayana.

Validitas konstrak dilakukan untuk mengetahui sejauhmana hasil tes mampu mengungkap suatu trait atau konstrak teoritik yang hendak diukur. Suatu aitem dikatakan valid apabila skor corrected total item correlation lebih besar daripada 0.30 . Apabila jumlah item tidak memenuhi setiap dimensi atau aspek dalam alat ukur berdasarkan jumlah yang diinginkan, maka skor corrected total item correlation dapat diturunkan menjadi 0,25 (Azwar, 2014).

Uji reliabilitas pada penelitian ini dilakukan untuk mengetahui sejauh mana hasil pengukuran tetap konsisten, apabila dilakukan pengukuran dua atau lebih dengan alat ukur yang sama (Siregar, 2014). Suatu alat ukur dikatakan memiliki reliabilitas yang baik, apabila alat ukur memiliki nilai reliabilitas lebih besar dari 0,70 (Ghozali, 2012). Uji reliabilitas skala self compassion dan psychological well-being menggunakan teknik pengukuran Croncbach Alpha pada program SPSS versi 16.0 for windows.

Hasil uji validitas skala self compassion memiliki koefisien korelasi aitem total berkisar 0,318 hingga 0,770. Hasil uji reliabilitas skala self compassion dengan menggunakan teknik Alpha Cronbach menunjukkan nilai koefisien Alpha $(\alpha)$ sebesar 0,943. Nilai koefisien Alpha ( $\alpha$ ) 0,943 berarti skala self compassion mampu mencerminkan 94,30\% nilai skor murni responden sehingga alat ukur dari skala self compassion dinyatakan layak untuk mengukur variabel self compassion.

Hasil uji validitas skala psychological well-being memiliki koefisien korelasi aitem total berkisar antara 0,252 hingga 0,703. Hasil uji reliabilitas skala psychological well-being menggunakan teknik Alpha Cronbach menunjukkan nilai koefisien Alpha $(\alpha)$ sebesar 0,915. Nilai koefisien Alpha $(\alpha)$ 0,915 berarti skala psychological well-being mampu mencerminkan $91,50 \%$ dari nilai skor murni responden sehingga alat ukur dari skala psychological well-being dinyatakan layak digunakan untuk mengukur variabel psychological well-being.

\section{Metode Pengumpulan Data}

Metode pengumpulan data dalam penelitian ini menggunakan teknik probability sampling yaitu teknik pengambilan sampel dengan memberikan peluang yang sama bagi anggota populasi untuk dipilih menjadi anggota sampel. Sampel dipilih menggunakan simple random sampling yaitu pengambilan anggota sampel dari populasi yang dilakukan secara acak tanpa memerhatikan strata dalam populasi (Sugiyono, 2013).

Tahap pertama, peneliti melakukan listing nama-nama sampel dalam populasi. Peneliti kemudian melakukan pengundian sampel secara acak dari 82 sampel, didapatkan 70 sampel dalam populasi. Alasan peneliti menggunakan 70 sampel berdasarkan acuan Azwar (2014) menjelaskan bahwa 60 sampel penelitian sudah dikatakan layak untuk memenuhi sampel dalam penelitian. Peneliti kemudian menyebarkan kuesioner online kepada 70 sampel yang telah terpilih melalui proses random dan terisi sebanyak 60 kuesioner. 10 sampel lainnya mengalami kesulitan mengakses internet untuk mengisi kuesioner secara online.

\section{Teknik Analisis Data}

Metode analisis statistik yang digunakan adalah teknik regresi linier sederhana. Analisis regresi linier sederhana bertujuan untuk melihat apakah satu variabel bebas (independent) memengaruhi satu variabel terikat (dependent) (Siregar, 2014). Apabila hasil probabilitas menunjukkan nilai signifikansi lebih kecil dari $0,05(\mathrm{p}<0,05)$ maka variabel bebas diyakini memiliki peran terhadap variabel tergantung.

\section{HASIL PENELITIAN}

\section{Karakteristik Subjek \\ Karakteristik Berdasarkan Usia}

Hasil deskripsi responden berdasarkan usia menunjukkan bahwa mayoritas pengajar muda berusia 23 tahun dengan persentase sebesar $31.7 \%$ atau sekitar 19 orang. Karakteristik responden berdasarkan usia dapat dilihat pada tabel 1 (terlampir).

Karakteristik Berdasarkan Jenis Kelamin

Hasil deskripsi responden berdasarkan jenis kelamin menunjukkan bahwa pengajar muda berjenis kelamin perempuan berjumlah 35 orang atau sekitar 58.3\% lebih banyak dibandingkan pengajar muda dengan jenis kelamin 
laki-laki yang berjumlah 25 orang atau sekitar $41.7 \%$. Hasil deskripsi responden berdasarkan jenis kelamin dapat dilihat pada tabel 2 (terlampir).

Karakteristik Berdasarkan Pendidikan Terakhir

Hasil deskripsi responden berdasarkan pendidikan terakhir menunjukan bahwa mayoritas pengajar muda yang mengikuti penelitian ini memiliki pendidikan terakhir yaitu Strata-1 (S1) sebanyak 56 orang atau sekitar $93.33 \%$ sedangkan pengajar muda dengan pendidikan terakhir Strata-2 (S2) sebanyak 4 orang atau sekitar 6.67\%. Hasil deskripsi responden berdasarkan pendidikan terakhir dapat dilihat pada tabel 3 (terlampir).

Karakteristik berdasarkan Daerah Penempatan

Berdasarkan daerah penempatan dapat dibedakan menjadi 11 kategori wilayah penempatan pengajar muda. Hasil deskripsi menunjukkan bahwa mayoritas pengajar muda yang mengikuti penelitian ini berada di wilayah Aceh Utara, Nanggroe Aceh Darussalam dengan persentase sebesar 13,3\% atau sekitar 8 orang dari total responden secara keseluruhan. Hasil deskripsi dapat dilihat pada tabel 4 (terlampir).

\section{Deskripsi dan Kategorisasi Data Penelitian}

Tujuan kategorisasi data penelitan adalah untuk menempatkan subjek ke dalam kelompok-kelompok yang terpisah secara berjenjang menurut suatu kontinum berdasarkan atribut yang diukur. Kontinum jenjang ini meliputi sangat rendah, rendah, sedang, tinggi, dan sangat tinggi. Penentuan kategorisasi dengan skor skala menggunakan nilai mean dan standar deviasi teoretis (Azwar, 2014). Rumus untuk menentukan kategorisasi data penelitian dapat dilihat pada tabel 5 (terlampir) dan hasil deskripsi statistik data penelitian yaitu self compassion dan psychological well-being dapat dilihat dan dirangkum pada tabel 6 (terlampir).

\section{Self-compassion}

Variabel self-compassion memiliki mean teoretis sebesar 85 dan mean empiris sebesar 107,48 dengan perbedaan mean sebesar 22,48 dan nilai t sebesar 18,192. Mean empiris yang diperoleh lebih besar daripada mean teoritis (mean empiris $>$ mean teoritis) menghasilkan sebuah kesimpulan bahwa pengajar muda memiliki self compassion pada taraf yang tinggi. Adapun kategorisasi variabel self compassion dapat dilihat pada tabel 7 (terlampir). Berdasarkan tabel dapat dilihat bahwa tidak terdapat pengajar muda dengan self compassion pada taraf yang rendah dan sangat rendah. Mayoritas pengajar muda memiliki self compassion pada taraf yang tinggi berjumlah 36 orang atau sekitar 60\%. Pengajar muda dengan self compassion pada taraf sangat tinggi sebanyak 23 orang atau sekitar $38,3 \%$ dan hanya 1 orang atau $1,7 \%$ pengajar muda yang memiliki self compassion pada taraf yang sedang. Kesimpulan yang diperoleh yaitu mayoritas pengajar muda memiliki self compassion pada taraf yang tinggi.

Psychological well-being

Variabel psychological well-being memiliki mean teoretis sebesar 87,5 dan mean empiris sebesar 110,12 dengan perbedaan mean sebesar 22,62 dan nilai t sebesar 19,611. Mean empiris yang diperoleh lebih besar daripada mean teoritis (mean empiris $>$ mean teoritis) menghasilkan sebuah kesimpulan bahwa pengajar muda memiliki psychological well-being pada taraf yang tinggi. Adapun kategorisasi psychological well-being dapat dilihat pada tabel 8 (terlampir). Berdasarkan tabel menunjukkan hasil bahwa tidak terdapat pengajar muda dengan psychological well-being pada taraf yang sedang, rendah, maupun sangat rendah. Mayoritas pengajar muda memiliki psychological well-being pada taraf yang tinggi berjumlah 43 orang atau sekitar 71,7\%. Pengajar muda dengan psychological well-being pada taraf yang sangat tinggi berjumlah 17 orang atau sekitar 28,3\%. Kesimpulan yang diperoleh adalah mayoritas pengajar muda memiliki psychological well-being pada taraf yang tinggi.

\section{Uji Normalitas}

Uji normalitas bertujuan untuk menguji apakah variabel memiliki distribusi yang normal atau tidak. Uji normalitas pada penelitian ini dilakukan dengan teknik KolmogorovSmirnov melalui program SPSS versi 16.0. Apabila nilai signifikansi lebih besar dari $0,05(\mathrm{p}>0,05)$ maka data tersebut terdistribusi secara normal (Siregar, 2014). Uji normalitas data penelitian dapat dilihat pada tabel 9 (terlampir).

Sebaran Data Variabel Self Compassion

Berdasarkan tabel diatas dapat dilihat bahwa variabel self compassion mempunyai nilai kolmogorov-smirnov sebesar 0.740 dengan nilai signifikasi 0.644 yang berarti lebih besar daripada $0,05(\mathrm{p}>0,05)$. Hal ini menunjukan bahwa data pada variabel self compassion berdistribusi normal.

Sebaran Data Variabel Psychological Well-Being

Berdasarkan tabel diatas dapat dilihat bahwa variabel psychological well-being mempunyai nilai kolmogorovsmirnov sebesar 1.031 dengan nilai signifikasi 0.238 yang berarti lebih besar daripada $0,05(\mathrm{p}>0,05)$. Hal ini menunjukan bahwa data pada variabel psychological well-being berdistribusi normal.

\section{Uji Linearitas}

Uji linieritas dilakukan untuk mengetahui apakah variabel bebas dan variabel tergantung memiliki hubungan yang linier atau tidak (Siregar, 2014). Priyatno (2012) menjelaskan bahwa data dikatakan linier apabila nilai signifikansi pada linearity lebih kecil dari $0,05(\mathrm{p}<0,05)$ dan nilai signifikansi pada deviation from linearity lebih besar dari $0,05(\mathrm{p}>0,05)$. Hasil uji linieritas dapat dilihat pada tabel 10 (terlampir). Berdasarkan hasil uji linieritas data pada tabel 10, variabel psychological well-being dan self compassion memiliki hubungan yang linier. Nilai signifikansi pada kolom linearity sebesar 0,000 $(\mathrm{p}<0,05)$ dan nilai signifikansi pada kolom deviation from linearity sebesar $0,799(>0,05)$. Oleh karena itu, dapat disimpulkan bahwa variabel psychological wellbeing dan self compassion memiliki hubungan yang linier.

\section{Uji Hipotesis}

Uji hipotesis pada penelitian ini menggunakan teknik regresi linier sederhana. Teknik regresi linier sederhana bertujuan untuk melihat apakah satu variabel bebas (independent) memengaruhi satu variabel terikat (dependent) (Siregar, 2014). Apabila hasil probabilitas menunjukkan nilai signifikansi lebih kecil dari $0,05(\mathrm{p}<0,05)$ maka variabel bebas diyakini memiliki peran terhadap variabel tergantung. Hasil uji regresi linier sederhana dapat dilihat pada tabel 11, 12, dan 13 (terlampir). 
Berdasarkan tabel 11, hasil uji regresi linier sederhana menunjukan bahwa koefisien regresi (R) adalah 0,792 dan koefisien determinasi ( $\mathrm{R}$ Square) adalah 0,628. Hal ini menunjukan bahwa variabel self compassion memberikan sumbangan efektif sebesar $62,80 \%$ terhadap psychological well-being, sedangkan sisanya sebesar $37,20 \%$ dipengaruhi oleh faktor-faktor lain yang tidak diteliti dalam penelitian ini sehingga dapat disimpulkan bahwa self compassion memiliki peran terhadap psychological well-being.

Berdasarkan tabel 12, didapatkan hasil bahwa nilai $\mathrm{F}$ hitung yaitu 97,814 dengan nilai signifikansi $0,000(p<0,05)$. Nilai signifikansi $(0,000)$ lebih kecil dari $0,05(\mathrm{p}<0,05)$ maka dapat disimpulkan bahwa model regresi dapat digunakan untuk memprediksi psychological well-being atau dapat dikatakan variabel self compassion memiliki peran terhadap psychological well-being.

Berdasarkan hasil yang terlihat pada tabel 13, diketahui bahwa variabel self compassion memiliki koefisien beta terstandarisasi 0,792 dengan nilai t sebesar 9,890 dan memiliki taraf signifikansi sebesar $0,000(\mathrm{p}<0,05)$ yang berarti bahwa self compassion berperan secara signifikan terhadap psychological well-being. Berdasarkan uraian tersebut, dapat disimpulkan bahwa hipotesis penelitian self compassion berperan terhadap psychological well-being pengajar muda di Indonesia Mengajar dapat diterima. Rangkuman hasil uji hipotesis penelitian dapat dilihat pada tabel 14 (terlampir).

\section{PEMBAHASAN DAN KESIMPULAN}

Berdasarkan hasil penelitian yang telah dipaparkan sebelumnya dan menggunakan teknik uji regresi linier sederhana didapatkan hasil bahwa hipotesis pada penelitian ini yaitu self compassion berperan terhadap psychological wellbeing pengajar muda di Indonesia Mengajar dapat diterima. Hipotesis dapat diterima dengan melihat nilai koefisien regresi yaitu 0,792 dengan $\mathrm{F}$ hitung sebesar 97.814 dengan taraf signifikansi $0,000(\mathrm{p}<0,05)$, maka model regresi bisa dipakai untuk memprediksi psychological well-being, atau dapat dikatakan bahwa self compassion berperan terhadap psychological well-being pengajar muda di Indonesia Mengajar.

Koefisien determinasi sebesar 0,628 menunjukkan bahwa variabel bebas yaitu self compassion memiliki peran sebesar $62,80 \%$ terhadap variabel tergantung yaitu psychological wellbeing. Kesimpulan yang diperoleh yaitu self compassion memiliki peran sebesar $62,80 \%$ terhadap psychological wellbeing yang dimiliki pengajar muda, sedangkan sisanya sebesar $37,20 \%$ dijelaskan oleh faktor-faktor lain yang tidak diteliti dalam penelitian ini.

Hasil koefisien beta terstandarisasi dari self compassion menunjukkan bahwa nilai sebesar 0,792 dan nilai $t$ sebesar 9.890 dengan taraf signifikansi $0,000 \quad(\mathrm{p}<0,05)$. Dapat disimpulkan bahwa self compassion memiliki peran terhadap psychological well-being pengajar muda di Indonesia Mengajar. Self compassion merupakan kemampuan individu untuk memberikan kebaikan dan perhatian kepada diri sendiri ketika mengalami kesulitan, tantangan, dan masalah dalam hidup serta memahami bahwa segala kesulitan, tantangan, dan masalah dalam hidup merupakan bagian dari pengalaman hidup manusia (Neff, 2011).

Neff dan Costigan (2014) menjelaskan bahwa memperlakukan diri sendiri dengan penuh kasih sayang dan kepedulian ketika menghadapi kesulitan, tantangan, dan masalah dalam hidup mampu meningkatkan psychological well-being dalam diri individu. Self compassion mampu merangkul dengan hangat emosi negatif dan menyeimbangkannya dengan emosi positif. Emosi positif yang dimiliki individu meliputi kepedulian terhadap diri sendiri, mampu memahami bahwa kesulitan, tantangan, dan masalah merupakan pengalaman hidup manusia serta mampu melihat situasi secara jelas tanpa harus memperkecil atau memperbesar situasi yang terjadi.

Self compassion mampu melindungi individu dari emosi negatif, memberikan keterampilan dalam mengelola emosi dengan baik, dan berpengaruh terhadap peningkatan psychological well-being dalam diri individu. Self compassion merupakan sumber utama dari kebahagiaan eudaimonik (psychological well-being). Ketika pendekatan hedonik (subjective well-being) mencari kebahagiaan dengan melibatkan pengalaman yang bahagia dan menghindari rasa sakit. Self compassion mampu memeluk rasa sakit dengan memberikan kebaikan terhadap diri sendiri (self kindness) ketika mengalami masalah, kesulitan dan penderitaan dalam hidup serta mampu meningkatkan kesejahteraan (well-being) dalam diri individu (Neff dan Costigan, 2014).

Hasil penelitian yang dilakukan Neff dan Chris Germer (dalam Neff dan Costigan, 2014) menunjukan bahwa self compassion khususnya aspek common humanity mampu meningkatkan keterampilan individu untuk bersikap imbang dalam memberikan kebaikan terhadap diri sendiri dan orang lain sehingga dapat berpengaruh terhadap peningkatan psychological well-being dalam diri individu khususnya pada dimensi kemampuan dalam menjalin hubungan yang positif dengan orang lain (positive relation with others).

Maslow dan Rogers (dalam Neff \& Costigan, 2014) menjelaskan bahwa kepribadian yang sehat menekankan penerimaan diri tanpa syarat sebagaimana self compassion khususnya pada komponen self kindness yaitu kemampuan individu untuk menerima diri apa adanya tanpa harus menghakimi atau menyalahkan diri sendiri ketika mengalami kegagalan, kesulitan dan ketidaksempurnaan dalam hidup sehingga individu mampu menerima diri secara positif, menyadari dan mengoptimalkan potensi diri sehingga dapat berpengaruh terhadap peningkatan psychological well-being khususnya pada dimensi pertumbuhan pribadi (personal growth).

Deskripsi statistik data penelitian menunjukkan bahwa mean teoritis dari variabel psychological well-being sebesar 87,5 dan mean empiris sebesar 110,20. Mean empiris lebih besar dari mean teoritis (mean empiris $>$ mean teoritis) yang artinya pengajar muda memiliki psychological well-being pada taraf yang tinggi. Hasil kategorisasi data variabel psychological 
well-being menunjukkan bahwa pengajar muda dengan psychological well-being pada taraf yang tinggi memiliki persentase sebesar 43 orang atau sekitar $71,7 \%$ dan psychological well-being pada taraf yang sangat tinggi sebesar 17 orang atau sekitar $28,3 \%$.

Hasil deskripsi responden menunjukan bahwa mayoritas pengajar muda memiliki pendidikan terakhir yaitu Strata-1 (S1) sebanyak 56 orang atau sekitar 93,33\% dan strata-2 (S2) sebanyak 4 orang atau sekitar 6,67\%. Faktor pendidikan dapat memengaruhi tingginya psychological well-being yang dimiliki individu. Semakin tinggi jenjang pendidikan yang dimiliki, maka semakin besar pengaruhnya dalam membantu individu untuk mencari solusi terhadap masalah yang terjadi dibandingkan individu dengan jenjang pendidikan yang rendah (Anggara, 2016).

Berdasarkan data yang didapatkan dari Indonesia Mengajar (2017) diketahui bahwa pengajar muda memiliki prestasi secara akademis maupun non-akademis dari berbagai bidang bertaraf nasional maupun Internasional. Prestasi tersebut diantaranya mahasiswa berprestasi, aktif membuat karya tulis ilmiah dan konferensi nasional dan internasional, aktif mengikuti program delegasi seperti Youth Cultural Forum di Malaysia, pertukaran pelajar AFS/YES serta mendirikan perpustakaan untuk meningkatkan minat membaca bagi masyarakat sekitar. Individu yang mampu mencapai tujuan yang diinginkan dan menghasilkan prestasi (achievement) mampu memberikan kepuasan dalam hidup dan berpengaruh terhadap peningkatan psychological well-being dalam diri individu (Prajitno, 2014).

Hasil deskripsi responden menunjukan bahwa sebagian besar pengajar muda berada dalam rentang usia 21 hingga 28 tahun. Menurut Papalia, Olds dan Feldman (2004) individu yang telah memasuki usia 20 hingga 40 tahun termasuk dalam rentang masa dewasa awal. Individu pada masa dewasa awal memiliki psychological well-being yang tinggi, karena individu pada masa dewasa awal menganggap dirinya telah mengalami kemajuan yang signifikan sejak masa remaja dan memiliki harapan yang tinggi di masa depan khususnya pada dimensi tujuan hidup (pupose in life) dan pertumbuhan pribadi (personal growth) (Singh, Mohan, \& Anasseri, 2012).

Hasil kategorisasi data variabel self compassion menjelaskan bahwa mean teoritis dari variabel self compassion sebesar 85 dan mean empiris sebesar 107,43. Mean empiris lebih besar dari mean teoritis (mean empiris $>$ mean teoritis) yang artinya pengajar muda memiliki self compassion pada taraf yang tinggi. Hasil kategorisasi data self compassion menunjukkan bahwa mayoritas pengajar muda memiliki self compassion pada taraf yang tinggi dengan persentase sebesar $60 \%$ atau 36 orang pengajar muda dari total secara keseluruhan.

Hasil tersebut menunjukan bahwa mayoritas pengajar muda memiliki self compassion pada taraf yang tinggi. Pemahaman pengajar muda bahwa segala tantangan, masalah dan kesulitan yang dihadapi merupakan pengalaman hidup yang dirasakan oleh pengajar muda lainnya dapat menjadi salah satu faktor tingginya self compassion. Pengajar muda mampu memahami keterhubungan pengalaman hidup dengan orang lain khususnya pengajar muda lain yang sedang bertugas di daerah penempatan lainnya sehingga pengajar muda tidak merasa hanya dirinya yang mengalami tantangan, kesulitan dan masalah selama bertugas di daerah pedalaman.

Pemahaman pengajar muda terhadap keterhubungan terhadap pengajar muda lainnya (common humanity) menjadi salah satu faktor yang memengaruhi tingginya self compassion pengajar muda. Self compassion mengaitkan keterkaitan dengan pengalaman hidup manusia (common humanity). Markus dan Kitayama (dalam Missilliana 2014) menjelaskan bahwa individu pada Budaya Asia mampu memahami segala masalah, kesulitan dan tantangan dalam hidup merupakan pengalaman hidup manusia sehingga individu pada Budaya Asia memiliki self compassion yang pada taraf yang lebih tinggi dibandingkan self compassion pada Budaya barat yang menekankan Budaya individualisme ketika menghadapi masalah, tantangan maupun kesulitan dalam hidup.

Adapun keterbatasan penelitian ini adalah data deskriptif dalam penelitian ini hanya membahas mengenai kategori usia, jenis kelamin, jenjang pendidikan, dan daerah penempatan pengajar muda. Penelitian ini belum membahas mengenai kelas sosial ekonomi, relasi sosial, dukungan sosial, spiritualitas, dan kepribadian yang dapat memengaruhi taraf psychological well-being dan self compassion. Penelitian ini secara rinci juga belum melakukan analisis tambahan dengan uji independent sample t-test untuk melihat perbedaan tingkat self compassion dan psychological well-being apabila dikategorikan berdasarkan usia, jenis kelamin dan tingkat pendidikan pada pengajar muda di Indonesia Mengajar.

Berdasarkan uraian tersebut, dapat disimpulkan bahwa self compassion berperan terhadap psychological well-being pengajar muda di Indonesia Mengajar. Psychological wellbeing pengajar muda di Indonesia Mengajar mayoritas tergolong tinggi. Self compassion pengajar muda di Indonesia Mengajar mayoritas tergolog tinggi. Adapun saran yang dapat diberikan yaitu pengajar muda diharapkan dapat mempertahankan psychological well-being yang tergolong tinggi dengan cara aktif mengikuti kegiatan kerelawanan seperti kegiatan sosial, keagamaan, maupun kelompok profesi. Pengajar muda juga diharapkan dapat terus mempertahankan self compassion yang tergolong tinggi dengan cara mempertahankan keterampilan dalam mengelola emosi dengan baik agar dapat membantu pengajar muda dalam menghadapi berbagai tantangan selama bertugas di daerah pedalaman.

Saran lain yang dapat diberikan yaitu bagi pihak Indonesia Mengajar diharapkan dapat mempertahankan psychological well-being pengajar muda yang tergolong tinggi dengan cara memberikan layanan konseling kepada pengajar muda yang sedang bertugas di daerah pedalaman. Adapun saran lainnya bagi pihak Indonesia Mengajar yaitu pada tahap seleksi dapat mempertimbangkan untuk memilih calon pengajar muda dengan self compassion yang baik. Pengajar muda dengan self compassion yang baik mampu melindungi diri dari berbagai emosi negatif serta memiliki keterampilan mengelola emosi 
dengan baik dalam menghadapi berbagai tantangan selama bertugas di daerah penempatan.

Saran lain untuk penelitian selanjutnya yaitu peneliti dapat mengangkat faktor-faktor lain seperti kelas sosial ekonomi, relasi sosial, dukungan sosial, spiritualitas, dan kepribadian yang dapat memengaruhi psychological well-being. Saran lainya yaitu peneliti dapat melakukan uji analisis lanjutan berupa uji independent sample t-test untuk melihat tingkat self compassion dan psychological well-being apabila dikategorikan berdasarkan usia, jenis kelamin dan tingkat pendidikan.

\section{DAFTAR PUSTAKA}

Anggara, O.F. (2016). Pengaruh expressive arts therapy terhadap dimensi psychological well-being pada anak jalanan di jaringan XYZ. (Thesis tidak dipublikasikan). Fakultas Psikologi Universitas Airlangga, Surabaya.

Azwar, S. (2014). Reliabilitas dan validitas. Yogyakarta: Pustaka Pelajar.

Clemente, M., Hezomi,H., Allahverdipour,H., Jafarabadi,M.A., \& Safaiana. (2016). Stress and psychological well-being: An explonatory study of the Iranian female adolescents. Journal of Child \& Adolescent Behavior, 4(1) 1-5.

Dewi, H.C. (2013). Psychological well-being pada petugas pemadam kebakaran di Jakarta. (Skripsi tidak dipublikasikan). Fakultas Psikologi Universitas Indonesia, Depok.

Febrinabilah, R., \& Listiyandini, R. (2016). Hubungan antara self compassion dengan resiliensi pada mantan pecandu narkoba dewasa awal. Prosiding konferensi nasional peneliti muda psikologi indonesia, 1(1), 19-28.

Ghozali, H. (2012). Aplikasi analisis multivariate dengan program IBM SPSS 20. Semarang: Badan Penerbit Universitas Dipenogoro.

Havighurst. (1985). Psikologi perkembangan. Surabaya: Sinar Wijaya.

Hurlock, E. (1980). Psikologi perkembangan: suatu pendekatan sepanjang rentang kehidupan. Jakarta: Erlangga.

Indonesiamengajar.org. (2017). Diunduh tanggal 23 April 2017 dari indonesiamengajar.org: https://www.indonesiamengajar.org

Issom, F. L., \& Makbulah, R. (2017). Pengaruh stres situasi kerja terhadap psychological well-being pada guru honorer Madrasah Ibtidaiyah di Kota Tanggerang. Perspektif Ilmu Pendidikan, 31, 61-67.

Missilliana, R. (2014). Self Compassion dan compassion for others pada mahasiswa Fakultas Psikologi UK Maranatha. (Naskah tidak dipublikasikan). Fakultas Psikologi Universitas Kristen Maranatha, Bandung.

Neff, K. (2003). Self compassion: An alternative conceptualization of a healthy attitude. Self and Identity, 2, 85-101.

Neff, K. (2011). Self compassion: stop beating yourself up and leave insecurity behind. Texas: Harper Collins Publishers.

Neff, K., \& Costigan, A. (2014). Self-compassion, wellbeing, and happiness. Psychology in österreich. 2(3), 114-117.

Papalia, D., Olds, S., \& Feldman, R. (2004). Human Development $\left(10^{\text {th }}\right.$ edition). New York: Mc. Graw Hill.

Prajitno, E.D. (2014). Hubungan psychological well-being dengan prestasi akademis pada mahasiswa Fakultas Psikologi
Universitas Kristen Satya Wacana. (Skripsi tidak dipublikasikan). Fakultas Psikologi Universitas Kristen Satya Wacana, Salatiga.

Priyatno, D. (2012). Belajar praktis analisis parametrik dan non parametrik dengan SPSS. Yogyakarta: Gava Media.

Renggani, A.F. (2017). Tantangan menjadi pengajar muda di Indonesia Mengajar: sebuah studi pendahuluan. Denpasar: Tidak dipublikasikan.

Ryff, C. (1989). Happiness is everything, or is it explorations on the meaning of psychological well-being. Journal of Personality and social psychology, 57(6), 1069-1081.

Santrock, J. (2012). Life span development: perkembangan masa hidup. Jakarta: Erlangga.

Setiawan, H. (2014). Psychological well-being pada guru honorer sekolah dasar di kecamatan wonotunggal kabupaten Batang. (Skripsi tidak dipublikasikan). Fakultas Ilmu Pendidikan Universitas Negeri Semarang, Semarang.

Seputro, Aulia R. (2016). Hubungan Antara self compassion dan subjective well-being pada pendeta. (Skripsi tidak dipublikasikan). Fakultas Psikologi. Universitas Katolik Soegijapranata, Semarang.

Singh, K., Mohan, J., \& Anasseri, M. (2012). Psychological wellbeing: dimensions, measurements and applications. Germany: LAP LAMBERT Academic Publishing.

Siregar, S. (2014). Statistik parametrik untuk penelitian kuantitatif. Jakarta: Bumi Aksara.

Sugiyono. (2013). Metode penelitian kombinasi (mixed methods). Bandung: Alfabeta.

Suparlan, M. (2006). Guru sebagai profesi. Yogyakarta: Hikayat Publishing.

Usman, A. (2017). The Effect of Psychological well-being on Employee Job Performance : Comparison Between The Employees of Projectized and Non-Projectized Organizations. Journal of Enterpreneurship and Organization Management, 6, 1-5.

Wijaya, N. (2016). Studi deskriptif mengenai self compassion pada guru sekolah luar biasa negeri B Bandung. (Skripsi tidak dipublikasikan). Fakultas Psikologi Universitas Kristen Maranatha, Bandung.

Zufar, Muhammad. (2015). Diunduh tanggal 2 September 2017 dari www.brilio.net: https://www.brilio.net/news/-ikutmajukan-pendidikan-bersama-komunitas-komunitas-iniyuk-151226v.html. 
A.F RENGGANI \& P.N WIDIASAVITRI

\section{LAMPIRAN}

Tabel 1

Deskripsi responden berdasarkan usia

Tabell.

Deskripsi Responden Berdasarkan Usia

\begin{tabular}{ccc}
\hline Usia & Jumlah & Persentase \\
\hline 21 & 1 & $1.7 \%$ \\
22 & 1 & $1.7 \%$ \\
23 & 19 & $31.7 \%$ \\
24 & 18 & $30 \%$ \\
25 & 12 & $20 \%$ \\
26 & 6 & $10 \%$ \\
27 & 2 & $3.3 \%$ \\
28 & 1 & $1.7 \%$ \\
\hline Total & 60 & $100 \%$ \\
\hline
\end{tabular}




\section{Tabel 2}

Deskripsi responden berdasarkan jenis kelamin

Tabel 2,

Deskripsi Responden Berdasarkan Jenis Kelamin

\begin{tabular}{ccc}
\hline Jenis Kelamin & Jumlah & Persentase \\
\hline Laki-laki & 25 & $41.7 \%$ \\
Perempuan & 35 & $58.3 \%$ \\
\hline Total & 60 & $100 \%$ \\
\hline
\end{tabular}


A.F RENGGANI \& P.N WIDIASAVITRI

Tabel 3

Deskripsi responden berdasarkan pendidikan terakhir

Tabel3,

Deskripsi Responden Berdasarkan Pendidikan Terakhir

\begin{tabular}{ccc}
\hline Pendidikan Terakhir & Jumlah & Persentase \\
\hline S1 & 56 & $93.33 \%$ \\
S2 & 4 & $6.67 \%$ \\
\hline Total & 60 & $100 \%$ \\
\hline
\end{tabular}


Tabel 4

Deskripsi responden berdasarkan daerah penempatan

Tabel 4 .

Deskripsi Responden Berdasarkan Daerah Penempatan

\begin{tabular}{ccc}
\hline Daerah Penempatan & Jumlah & Persentase \\
\hline Aceh Utara, Nanggroe Aceh Darussalam & 8 & $13,3 \%$ \\
Banggai, Sulawesi Tengah & 7 & $11,7 \%$ \\
Hulu Sungai Selatan, Kalimantan Selatan & 7 & $11.7 \%$ \\
Konawe, Sulawesi Tenggara & 5 & $8,3 \%$ \\
Maluku Barat Daya, Maluku & 2 & $3,3 \%$ \\
Musi Rawas, Sumatera Selatan & 6 & $10 \%$ \\
Natuna, Kepulauan Riau & 7 & $11,7 \%$ \\
Nunukan, Kalimantan Utara & 5 & $8,3 \%$ \\
Pegunungan Bintang, Papua Timur & 4 & $6,7 \%$ \\
Sabu Raijua, Nusa Tenggara Timur & 5 & $8,3 \%$ \\
Yapen, Papua Barat & 4 & $6,7 \%$ \\
\hline Total & 60 & $100 \%$ \\
\hline
\end{tabular}


A.F RENGGANI \& P.N WIDIASAVITRI

Tabel 5

Rumus kategorisasi data penelitian

Tabel 5 ,

Rumus Kategorisasi Data Penelitian

\begin{tabular}{cc}
\hline Rentang Nilai & Kategori \\
\hline $\mathrm{X} \leq(\mu-(1,5 \times \sigma))$ & Sangat Rendah \\
$(\mu-(1,5 \times \sigma))<\mathrm{X} \leq(\mu-(0,5 \times \sigma))$ & Rendah \\
$(\mu-(0,5 \times \sigma))<\mathrm{X} \leq(\mu+(0,5 \times \sigma))$ & Sedang \\
$(\mu+(0,5 \times \sigma))<\mathrm{X} \leq(\mu+(1,5 \times \sigma))$ & Tinggi \\
$(\mu+(1,5 \times \sigma))<\mathrm{X}$ & Sangat Tinggi \\
\hline
\end{tabular}

Keterangan: $\mu=$ mean teoretis, $\sigma=$ standar deviasi teoretis 
A.F RENGGANI \& P.N WIDIASAVITRI

Tabel 6

Deskripsi data penelitian

Hasil deskripsi data penelitian ditunjukan pada tabel 1 sebagai berikut

\begin{tabular}{ccccccccc}
\hline Variabel & $\mathrm{N}$ & Mean & Mean & Std. & Std. & Sebaran & Sebaran & Nilai t \\
& & & Teoretis & Empiris & $\begin{array}{c}\text { Deviasi } \\
\text { Teoretis }\end{array}$ & $\begin{array}{c}\text { Deviasi } \\
\text { Empiris }\end{array}$ & $\begin{array}{c}\text { Teoretis } \\
\text { Empiris }\end{array}$ & \\
\hline SC & 60 & 85 & 107,48 & 17 & 9,573 & $34-136$ & $92-132$ & 18,192 \\
PWB & 60 & 87,5 & 110,12 & 17,5 & 8,933 & $35-140$ & $94-132$ & 19,611 \\
\hline
\end{tabular}


A.F RENGGANI \& P.N WIDIASAVITRI

Tabel 7

Kategorisasi self-compassion

Tabel 7,

Kategorisasi Self Compassion

\begin{tabular}{cccc}
\hline Rentang Nilai & Kategori & Jumlah & Persentase \\
\hline $\mathrm{X} \leq 59,5$ & Sangat Rendah & 0 & $0 \%$ \\
$59,5<\mathrm{X} \leq 76,5$ & Rendah & 0 & $0 \%$ \\
$76,5<\mathrm{X} \leq 93,5$ & Sedang & 1 & $1,7 \%$ \\
$93,5<\mathrm{X} \leq 110,5$ & Tinggi & 36 & $60 \%$ \\
$110,5<\mathrm{X}$ & Sangat Tinggi & 23 & $38,3 \%$ \\
\hline
\end{tabular}


Tabel 8

Kategorisasi psychological well-being

Tabel 8.

Kategorisasi psychological well-being

\begin{tabular}{cccc}
\hline Rentang Nilai & Kategori & Jumlah & Persentase \\
\hline $\mathrm{X} \leq 61,25$ & Sangat Rendah & 0 & $0 \%$ \\
$61,25<\mathrm{X} \leq 78,75$ & Rendah & 0 & $0 \%$ \\
$78,75<\mathrm{X} \leq 96,25$ & Sedang & 0 & $0 \%$ \\
$96,25<\mathrm{X} \leq 113,75$ & Tinggi & 43 & $71,7 \%$ \\
$113,75<\mathrm{X}$ & Sangat Tinggi & 17 & $28,3 \%$ \\
\hline & Total & 60 & $100 \%$ \\
\hline
\end{tabular}


A.F RENGGANI \& P.N WIDIASAVITRI

Tabel 9

Hasil uji normalitas

Tabel 2.

Hasil Uji Normalitas

\begin{tabular}{cccc}
\hline Variabel & $\begin{array}{c}\text { Kolmogorov } \\
\text { Smirnov }\end{array}$ & $\begin{array}{c}\text { Asymp.Sig } \\
(2 \text {-tailed })(\mathrm{p})\end{array}$ & Kesimpulan \\
\hline SelfCompassion & 0.740 & $0.644(\mathrm{p}>0,05)$ & Data Nomal \\
Psychological Well-Being & 1.031 & $0.238(\mathrm{p}>0,05)$ & Data Nomal \\
\hline
\end{tabular}


Tabel 10

Hasil uji linearitas

Tabel10.

Hasil Uji Linieritas

\begin{tabular}{|c|c|c|c|c|c|}
\hline & & & & $\mathbf{F}$ & Sig. \\
\hline Psychological & Between Groups & Combined & & 4.003 & 0.000 \\
\hline \multicolumn{6}{|l|}{ Well- } \\
\hline & & Linearity & & 86.048 & 0.000 \\
\hline \multirow{2}{*}{ Compassion } & & Deviation & from & 0.721 & 0.799 \\
\hline & & Linearity & & & \\
\hline
\end{tabular}


A.F RENGGANI \& P.N WIDIASAVITRI

Tabel 11

Hasil uji regresi linear sederhana self-compassion terhadap psychological well-being

Tabell1.

Hasil Uji Regresi Linier Sederhana Self Compassion terhadap Psychological Well-Being

$\begin{array}{llll}R & \text { R Square } & \text { Adjusted R Square } & \text { Std. Error of the Estimate }\end{array}$

\begin{tabular}{llll}
\hline $0,792^{\mathrm{a}}$ & 0,628 & 0,621 & 5,497
\end{tabular}

a. Predictors: (Constant), SelfCompassion

b. Dependent Variable: Psychological Well-Being 


\section{Tabel 12}

Hasil uji regresi linear sederhana signifikansi nilai $\mathrm{F}$

\section{Tabel 12.}

Hasil Uji Regresi Linier Sederhana Signifikansi Nilai F

\begin{tabular}{cccccc}
\hline Model & Sum of Squares & Df & Mean Square & F & Sig. \\
\hline Regression & 2955.611 & 1 & 2955.611 & 97.814 & 0.000 \\
& & & & & \\
\hline Residual & 1752.572 & 58 & 30.217 & \\
& & & & & \\
\hline Total & 4708.183 & 59 & & & \\
& & & & & \\
\hline
\end{tabular}

a. Predictors: (Constant), SelfCompassion

b. Dependent Variable: Psychological Well-Being 
A.F RENGGANI \& P.N WIDIASAVITRI

Tabel 13

Hasil uji regresi linear sederhana nilai koefisien beta dan nilai $\mathrm{T}$ variabel self compassion terhadap psychological well-being

Tabel 13.

Hasil Uji Regresi Linear Sederhana Nilai Koefisien Beta dan Nilai t Variabel Self Compassion terhadap Psychological Well-Being

\begin{tabular}{lccccc}
\hline Model & Unstandardized & Coefficients & $\begin{array}{c}\text { Standardized } \\
\text { Coefficients }\end{array}$ & T & \\
& & & & \\
\cline { 2 - 5 } & B & Std. Error & Beta & \\
\hline (Constant) & 30,650 & 8,066 & & 3,800 & 0,000 \\
\hline Self Compassion & 0,739 & 0,075 & 0,792 & 9,890 & 0,000 \\
\hline
\end{tabular}


Tabel 14

Rangkuman uji hipotesis penelitian

\section{Tabel 14.}

Tabel Rangkuman Uji Hipotesis Penelitian

\begin{tabular}{lcc}
\hline No & Hipotesis Penelitian & Hasil \\
\hline $\begin{array}{l}\text { 1. Ho: Self compassion tidak berperan terhadap psychological } \\
\text { well-being pengajarmuda di Indonesia Mengajar }\end{array}$ & Ditolak \\
\hline & 2. Ha: Self compassion berperan terhadap psychological well-being & Diterima \\
& pengajarmuda di Indonesia Mengajar &
\end{tabular}

